Journal of Telenursing (JOTING)

Volume 3, Nomor 1, Juni 2021

e-ISSN: 2684-8988

p-ISSN: 2684-8996

DOI: https://doi.org/10.31539/joting.v3i1.2111

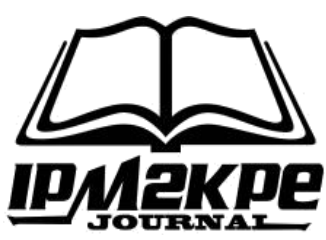

\title{
EDUKASI DIABETES TERHADAP PENURUNAN GLUKOSA DARAH PADA PENDERITA DIABETES MELLITUS TIPE 2
}

\author{
I Dewa Ayu Rismayanti ${ }^{1}$, I Made Sundayana ${ }^{2}$, Putu Agus Ariana ${ }^{3}$, Mochamad Heri ${ }^{4}$ \\ Sekolah Tinggi Ilmu Kesehatan Buleleng ${ }^{1,2,3,4}$ \\ i.dewa.ayu.rismayanti-2019@fkp.unair.ac.id ${ }^{1}$
}

\begin{abstract}
ABSTRAK
Penelitian ini bertujuan untuk mengetahui pengaruh edukasi diabetes terhadap kadar glukosa darah pada pasien DM tipe 2. Desain penelitian yang digunakan adalah preeksperimental dengan one group pre-post-test design. Hasil penelitian menunjukkan adanya penurunan kadar glukosa darah setelah dilakukan intervensi berupa edukasi diabetes dengan $p$-value $=0,000$. Kadar gula darah rata-rata (mean) sebelum intervensi adalah sebesar 244,19 dan setelah intervensi sebesar 166,06. Simpulan, pemberian edukasi diabetes sebagai salah satu penatalaksanaan diabetes dapat mempengaruhi manajemen diri pasien DM tipe 2, salah satunya dengan monitoring gula darah. Keberhasilan pemberian edukasi dapat dipengaruhi oleh beberapa faktor, seperti faktor pasien, pendidik atau pemberi edukasi dan lamanya edukasi yang diberikan.
\end{abstract}

Kata Kunci: Diabetes Mellitus Tipe 2, Edukasi, Glukosa Darah, Manajemen Diri

\section{ABSTRACT}

This study aims to determine the effect of diabetes education on blood glucose levels in type 2 DM patients. The research design used was pre-experimental with one group pre-post-test design. The results showed decreased blood glucose levels after intervention in diabetes education with a p-value $=0.000$. The mean blood sugar level before the intervention was 244.19 and after the intervention was 166.06. In conclusion, diabetes education as diabetes management can affect type 2 DM patients' selfmanagement, one of which is by monitoring blood sugar. Providing education can be influenced by several factors, such as patient factors, educators or education provider's factors, and the length of the education supplied.

Keywords: Type 2 Diabetes Mellitus, Education, Blood Glucose, Self Management

\section{PENDAHULUAN}

Diabetes Mellitus (DM) merupakan salah satu Penyakit Tidak Menular (PTM) dengan angka kejadian yang selalu meningkat tiap tahunnya. Manajemen diri merupakan mekanisme utama untuk mencegah terjadinya keparahan atau komplikasi lanjut yang dapat terjadi pada pasien DM. Namun, manajemen diri pada pasien DM masih belum optimal yang disebabkan oleh beberapa faktor seperti kurangnya pengetahuan dan kesalahan informasi tentang penyakit atau pengobatan (Pereira et al., 2019). Masalah diabetes merupakan salah satu isu penting di Indonesia. Berdasarkan data International Diabetes Federation tahun 2019, ada 463 juta orang dewasa (usia 2079 tahun) yang mengalami DM di dunia pada tahun 2019 dan pada tahun 2045 
angkanya diperkirakan akan meningkat menjadi 700 juta (Cho et al., 2018). Insiden DM di Indonesia meningkat dari tahun 2013 sebesar 6,9\% menjadi 10,9\% pada tahun 2018. Prevalensi DM di Provinsi Bali juga meningkat, mulai dari 1,3\% pada tahun 2013 dan meningkat menjadi 1,7\% pada tahun 2018. Jumlah penderita DM tipe 2 di Kabupaten Buleleng cukup tinggi yaitu mencapai 7.841 orang (Kementrian Kesehatan Republik Indonesia, 2018).

Kontrol gula darah merupakan kunci keberhasilan perawatan penderita DM (Luthfa, 2019). DM merupakan penyakit kronis yang terjadi saat pankreas tidak mampu menghasilkan insulin (Hormon yang berperan dalam regulasi gula darah) sehingga penderita DM akan mengalami peningkatan kadar gula darah (Zamaa \& Sainudin, 2019; Setyawati et al., 2020). Gula darah yang tidak terkontrol dengan baik cenderung menyebabkan berbagai komplikasi, kecacatan hingga kematian (Forbes \& Cooper, 2013). Edukasi merupakan salah satu dari empat pilar penatalaksanaan DM. Tujuan penatalaksanaan berupa edukasi adalah untuk meningkatkan pengetahuan pasien DM tentang penyakit dan manajemen pengobatan yang benar. Selain itu, kegiatan edukasi juga dapat meningkatkan promosi hidup sehat di masyarakat (Hong et al., 2020).

Edukasi menjadi elemen penting dalam perawatan pasien DM, selain itu edukasi juga diperlukan bagi pasien DM yang memiliki risiko tinggi mengalami komplikasi. Salah satu pendekatan edukasi dalam manajemen DM adalah Diabetes SelfManagement Education (DSME). Tujuan yang dicapai dalam pelaksanaan DSME yaitu memberikan dukungan informasi dalam pengambilan keputusan, perilaku perawatan diri, pemecahan masalah dan kerjasama aktif dengan tim kesehatan dan untuk meningkatkan hasil klinis, status kesehatan dan kualitas hidup (Bekele et al., 2020). Selain itu, DSME membantu orang dengan pradiabetes dalam melaksanakan dan mempertahankan perilaku yang diperlukan untuk mengelola kondisinya secara terusmenerus. DSME pada penderita DM merupakan hal penting yang harus dilakukan. DSME adalah suatu proses edukasi yang berkelanjutan untuk memfasilitasi pengetahuan, keterampilan dan kemampuan yang diperlukan untuk perawatan diri pasien DM (Rhinehart et al., 2017).

DSME diharapkan akan meningkatkan manajemen diri penderita DM dalam menjalankan pilar manajemen DM yang lain baik terapi farmakologis maupun latihan fisik. Dalam DSME pemberian edukasi memiliki standar kurikulum yang berisi penjelasan tentang penyakit, pola makan, aktivitas fisik, pemantauan gula darah, pencegahan komplikasi hingga manajemen diri dalam melakukan perubahan kesehatan dan perilaku (Bekele et al., 2021). Edukasi yang baik melalui DSME diharapkan akan meningkatkan manajemen diri dari pasien DM terutama dalam melakukan kontrol gula darah (Funnell et al., 2012).

Penelitian yang dilakukan oleh Anggraeni et al., (2018) menemukan bahwa terdapat pengaruh yang signifikan pemberian DSME/S terhadap kualitas hidup pasien DM tipe 2. DSME/S dapat meningkatkan pengetahuan dan kemampuan perawatan diri pasien dalam mengontrol gula darah dan mencegah komplikasi yang bisa mempengaruhi kualitas hidupnya. Penelitian lain yang dilakukan oleh Sari et al., (2018) menunjukkan bahwa tidak ada perbedaan signifikan pada pengetahuan kader sebelum dan sesudah pelatihan, sedangkan ada perbedaan signifikan pada self-efficacy pada kader sebelum dan sesudah pelatihan.

Berdasarkan hasil analisis pada penelitian terdahulu, sejauh ini belum ada penelitian yang spesifik meneliti tentang pemberian edukasi kesehatan Diabetes SelfManagement Education (DSME) terhadap penurunan glukosa darah pasien DM tipe 2. 
Oleh karena itu, peneliti tertarik untuk mengkaji mengenai pengaruh pemberian edukasi kesehatan tersebut agar informasi yang ditemukan dapat digunakan sebagai acuan dalam penatalaksanaan diabetes khususnya pada pasien DM tipe 2.

\section{METODE PENELITIAN}

Metode penelitian yang digunakan adalah penelitian kuantitatif. Desain dari penelitian ini adalah pra-eksperimental dengan rancangan one group pre-posttest design yaitu mengungkapkan hubungan sebab akibat dengan cara melibatkan satu kelompok subjek. Penelitian ini dilakukan di salah satu Puskesmas di wilayah Buleleng Bali pada bulan Januari 2021. Besar sampel penelitian ini adalah 52 pasien DM dengan kriteria inklusi merupakan pasien DM tipe 2 dan telah menderita penyakit DM selama 1-3 tahun terakhir. Pengambilan sampel menggunakan metode non-probability sampling yaitu total sampling dimana jumlah sampel yang digunakan sama dengan jumlah populasi yang ada di tempat penelitian tersebut.

Penelitian dimulai dengan melakukan pengukuran gula darah awal pada seluruh responden yang kemudian dilanjutkan dengan pemberian edukasi. Edukasi diabetes yang dilakukan berpedoman pada materi Diabetes Self-Management Education (DSME) yang dikemas dalam bentuk Satuan Acara Penyuluhan (SAP). SAP digunakan sebagai acuan dalam pelaksanaan intervensi pemberian edukasi. SAP dibagi menjadi 6 sesi dalam 6 minggu, setiap sesi dilakukan kurang lebih 60 menit dengan topik yang diberikan pada tiap sesinya berbeda. Instrumen lain yang digunakan adalah SOP pengukuran glukosa darah yang digunakan sebelum dan setelah intervensi edukasi selesai dilakukan. SOP terdiri dari 5 tahapa yaitu tahap praorientasi, orientasi, kerja, terminasi dan dokumentasi.

\section{HASIL PENELITIAN}

\section{Karakteristik Responden}

Berikut ini merupakan hasil dari analisis deskriptif tiap variabel dan hasil uji statistik pengukuran gula darah sebelum dan sesudah pemberian intervensi edukasi diabetes. Tabel 1 dan 2 menunjukkan distribusi karakteristik responden penelitian.

Tabel. 1

Data Demografis Jenis Kelamin Responden Penelitian

\begin{tabular}{cccc}
\hline $\begin{array}{c}\text { Karakteristik Demografi } \\
\text { Responden }\end{array}$ & Kategori & $\begin{array}{c}\text { Frekuensi } \\
(\mathbf{f})\end{array}$ & $\begin{array}{c}\text { Persentase } \\
(\%)\end{array}$ \\
\hline Jenis Kelamin & Laki-Laki & 28 & 53,8 \\
\cline { 2 - 4 } & Perempuan & 24 & 46,2 \\
\cline { 2 - 4 } & Total & 52 & 100 \\
\hline
\end{tabular}

Berdasarkan karakteristik jenis kelamin, diketahui mayoritas responden adalah laki-laki sebanyak 28 orang $(53,8 \%)$ dan sisanya yaitu 24 orang berjenis kelamin perempuan $(46,2 \%)$.

Tabel. 2

Data Demografis Usia Responden Penelitian

\begin{tabular}{cccccc}
\hline $\begin{array}{c}\text { Karakteristik } \\
\text { Demografi Responden }\end{array}$ & N & Min. & Max. & Mean & SD \\
\hline Usia & 52 & 48 & 75 & 58,00 & 7,097 \\
\hline
\end{tabular}


Berdasarkan karakteristik usia, diketahui usia termuda dari responden penelitian adalah 48 tahun dan usia paling tua adalah 75 tahun dengan nilai standar deviasi sebesar 7,097 .

Tabel. 3

Hasil Pengukuran Gula Darah Sebelum dan Sesudah Intervensi Edukasi Diabetes

\begin{tabular}{ccccc}
\hline Kategori & Mean & $\mathrm{N}$ & Std. Deviation & Std. Error Mean \\
\hline Pre-Test & 244.19 & 52 & 51.34 & 7.12 \\
\hline Post-Test & 166.06 & 52 & 35.63 & 4.94 \\
\hline
\end{tabular}

Berdasarkan hasil pengukuran gula darah, diketahui rata-rata gula darah sebelum diberikan edukasi adalah 244,19 dengan standar deviasi (SD) sebesar 51,34. Nilai ratarata gula darah mengalami penurunan setelah dilakukan intervensi edukasi diabetes yaitu 166,06 dengan standar deviasi sebesar 35,63.

Tabel. 4

Hasil Uji Statistik Paired t-test

\begin{tabular}{cccccccccc}
\hline \multicolumn{10}{c}{$95 \%$ Confidence Interval of the Difference } \\
\hline $\begin{array}{c}\text { Paired t- } \\
\text { test }\end{array}$ & Mean & $\begin{array}{c}\text { Std. } \\
\text { Deviation }\end{array}$ & $\begin{array}{c}\text { Std. Error } \\
\text { Mean }\end{array}$ & Lower & Upper & $\mathrm{t}$ & $\mathrm{df}$ & $\begin{array}{c}\text { Sig. (2- } \\
\text { tailed) }\end{array}$ \\
\hline $\begin{array}{c}\text { Pre-Test- } \\
\text { Post-Test }\end{array}$ & 78.13 & 41.91 & 5.81 & 66.47 & 89.80 & 13.44 & 51 & .000 \\
\hline
\end{tabular}

Tabel 4 menunjukkan hasil uji paired t-test dari hasil pemeriksaan gula darah sebelum dan sesudah pemberian edukasi diabetes. Data menunjukkan bahwa terdapat pengaruh antara pemberian edukasi diabetes terhadap penurunan glukosa darah pasien DM Tipe 2 dengan nilai signifikansi $\mathrm{p}=0,000$ dan nilai rata-rata 78,13 dengan standar deviasi sebesar 41,91.

\section{PEMBAHASAN}

Hasil penelitian menunjukkan bahwa mayoritas responden adalah laki-laki. Tingginya prevalensi dan persentase kematian akibat diabetes mellitus menyebabkan perlunya penelusuran mengenai survei penyakit diabetes mellitus agar angka morbiditas dan mortalitas disetiap tahunya dapat diminimalisir. Jenis kelamin menjadi salah satu faktor pencetus terjadinya DM. Hal ini dibuktikan oleh penelitian yang dilakukan oleh Nababan et al., (2018) yang mendapatkan hasil bahwa variabel yang berhubungan dengan kadar gula darah puasa adalah umur, riwayat keturunan, jenis kelamin dan pola makan.

Penelitian lain yang dilakukan oleh Anggraeni et al., (2018) menunjukkan bahwa terdapat pengaruh yang signifikan antara Diabetes Mellitus Self Management Education dan dukungan terhadap kualitas hidup pasien DM tipe 2. Laki-laki diketahui lebih dominan mengalami kondisi kadar gula darah tinggi dibadingkan dengan wanita. Hal ini sejalan dengan penelitian yang dilakukan oleh Yosmar et al., (2018) dengan hasil bahwa laki-laki lebih berpeluang terkena diabetes dibandingkan dengan perempuan. Hal serupa juga disampaikan oleh International Diabetes Federation (IDF) bahwa penderita diabetes berjenis kelamin laki-laki jumlahnya 14 juta lebih banyak dibandingkan penderita perempuan (Cho et al., 2018). 
Usia juga berpengaruh terhadap kejadian DM. Responden yang masuk dalam usia lansia awal atau tergolong lansia akan lebih cenderung menderita DM. Hal ini disebabkan karena usia yang semakin tua akan berpengaruh terhadap melambatnya kerja organ tubuh (Ang, 2020). Setiap orang pasti mengalami proses degereratif oleh karena faktor bertambahnya usia. Proses degeneratif yang terjadi diantaranya adalah penyusutan otot, penyusutan lemak sub kutan dan melambatnya kinerja organ-organ tubuh. Usia berpengaruh terhadap peningkatan risiko DM, semakin tua usia seseorang akan berdampak pada penurunan fleksibelitas dan kekuatan organ serta fungsinya dalam tubuh (Yosmar et al., 2018).

Diabetes mellitus didefinisikan sebagai suatu penyakit atau gangguan metabolisme kronis dengan multietiologi yang ditandai dengan tingginya kadar gula darah disertai dengan gangguan metabolisme karbohidrat, lipid dan protein sebagai akibat insufisiensi fungsi insulin (Kretchy et al., 2020; Sartika et al., 2020). Insufisiensi insulin dapat disebabkan oleh gangguan atau defesiensi produksi insulin oleh sel-sel beta Langerhans kelenjar pankreas atau disebabkan oleh kurang responsifnya sel-sel tubuh terhadap insulin (Yosmar et al., 2018; Andari et al., 2020). Salah satu dari 4 pilar penanganan DM adalah pendidikan kesehatan. Perawat sebagai seorang edukator dan konselor bagi pasien dapat memberikan bantuan kepada pasien dalam bentuk supportive educative system dengan memberikan pendidikan kesehatan yang bertujuan untuk memandirikan pasien dalam melakukan manajemen diri.

Hasil penelitian menunjukkan adanya penurunan kadar gula darah pada pasien DM. Responden yang mengalami penurunan kadar gula disebabkan karena responden sangat kooperatif dan bersungguh-sungguh dalam mengikuti dan mendengarkan saat materi DSME dijelaskan. Menurut Hardika (2018) DSME merupakan suatu proses yang dilakukan untuk memfasilitasi pengetahuan, keterampilan dan kemampuan pasien DM untuk melakukan perawatan mandiri. Menurut penelitian yang dilakukan oleh Pranata et al., (2020) edukasi pasien dan keluarga dengan menggunakan booklet memberikan perubahan pada pengetahuan self-care DM.

\section{SIMPULAN}

Ada pengaruh pemberian intervensi edukasi diabetes berbasis DSME terhadap penurunan kadar glukosa darah pada pasien DM tipe 2. Sebagai salah satu penatalaksanaan diabetes, pemberian edukasi ini dapat mempengaruhi manajemen diri pasien DM tipe 2, salah satunya dengan monitoring gula darah. Keberhasilan pemberian edukasi dapat dipengaruhi oleh beberapa faktor, seperti faktor pasien, pendidik atau pemberi edukasi dan lamanya edukasi yang diberikan.

\section{SARAN}

Diharapkan penelitian ini dapat menjadi salah satu dasar ataupun acuan dalam penatalaksanaan diabetes khususnya pada pasien DM tipe 2. Edukasi diabetes dengan berpedoman pada DSME terbukti memberikan pengaruh terhadap peningkatan manajemen diri pasien DM tipe 2 khususnya pada kemampuan dalam monitoring gula darah. Tenaga kesehatan khususnya perawat dapat memberikan edukasi yang lebih masif dan optimal kepada pasien DM tipe 2 khususnya terkait penyakit, obat dan manajemen diri, sehingga dapat menurunkan angka terjadinya komplikasi penyerta dan atau kematian. 


\section{DAFTAR PUSTAKA}

Andari, F., Vioneery, D., Panzilion, P., Nurhayati, N., \& Padila, P. (2020). Penurunan Tekanan Darah pada Lansia dengan Senam Ergonomis. Journal of Telenursing (JOTING), 2(1), 81-90. https://doi.org/10.31539/joting.v2i1.859

Ang, G. Y. (2020). Age of Onset of Diabetes and All-Cause Mortality. Word Journal of Diabetes, 11(4), 90-149. http://dx.doi.org/10.4239/wjd.v11.i4.95

Anggraeni, A. F. N., Rondhianto, \& Juliningrum, P. P. (2018). Pengaruh Diabetes SelfManagement Education and Support (DSME/S) terhadap Kualitas Hidup pada Pasien Diabetes Melitus Tipe 2. E-Jurnal Pustaka Kesehatan, 6(3), 453-460. https://jurnal.unej.ac.id/index.php/JPK/article/view/11688

Bekele, B. B., Negash, S., Bogale, B., Tesfaye, M., Getachew, D., Weldekidan, F., \& Balcha, B. (2020). The Effectiveness of Diabetes Self-Management Education (DSME) on Glycemic Control Among T2DM Patients Randomized Control Trial: Systematic Review and Meta-Analysis Protocol. Journal of Diabetes \& Metabolic Disorders, 1631-1637. https://doi.org/10.1007/s40200-020-00584-3

Bekele, B. B., Negash, S., Bogale, B., Tesfaye, M., Getachew, D., Weldekidan, F., \& Balcha, B. (2021). Effect of Diabetes Self-Management Education (DSME) on Glycated Hemoglobin (HbA1c) Level among Patients with T2DM: Systematic Review and Meta-Analysis of Randomized Controlled Trials. Diabetes and Metabolic Syndrome: Clinical Research and Reviews, 15(10), 177-185 https://doi.org/10.1016/j.dsx.2020.12.030

Cho, N. H., Shaw, J. E., Karuranga, S., Huang, Y., Fernandes, J. D. D. R., Ohlrogge, A. W., \& Malanda, B. (2018). IDF Diabetes Atlas: Global Estimates of Diabetes Prevalence for 2017 and Projections for 2045. Diabetes Research and Clinical Practice, 138, 271-281. https://doi.org/10.1016/j.diabres.2018.02.023

Forbes, J. M., \& Cooper, M. E. (2013). Mechanisms of Diabetic Complications. Physiological Reviews, 93(1), 137-188. https://doi.org/10.1152/physrev.00045.2011

Funnell, M. M., Brown, T. L., Childs, B. P., Haas, L. B., Hosey, G. M., Jensen, B., Maryniuk, M., Peyrot, M., Piette, J. D., Reader, D., Siminerio, L. M., Weinger, K., \& Weiss, M. A. (2012). National Standards for Diabetes Self-Management Education. Diabetes Educator, 33(4), 599-614. https://doi.org/10.1177/0145721707305880

Hardika, B. D. (2018). Penurunan Gula Darah pada Pasien Diabetes Melitus Tipe II $\begin{array}{lllll}\text { Melalui Senam Kaki Diabetes. Medisains, } & \text { 16(2), } 60 .\end{array}$ https://doi.org/10.30595/medisains.v16i2.2759

Hong, Y. R., Jo, A., Cardel, M., Huo, J., \& Mainous, A. G. (2020). Patient-Provider Communication with Teach-Back, Patient-Centered Diabetes Care, and Diabetes Care Education. Patient Education and Counseling, 103(12), 2443-2450 https://doi.org/10.1016/j.pec.2020.05.029

Kementrian Kesehatan Republik Indonesia. (2018). Profil Kesehatan Indonesia Tahun 2018. https://pusdatin.kemkes.go.id/resources/download/pusdatin/profilkesehatan-indonesia/PROFIL_KESEHATAN_2018_1.pdf

Kretchy, I. A., Koduah, A., Ohene-Agyei, T., Boima, V., \& Appiah, B. (2020). The Association between Diabetes-Related Distress and Fear of Hypoglycaemia in Patients with Type 2 Diabetes Mellitus: A Cross-Sectional Descriptive Study. Journal of Diabetes Research, 1-10. https://doi.org/10.1155/2020/4760624

Luthfa, I. (2019). Implementasi Selfcare Activity Penderita Diabetes Mellitus di 
Wilayah Puskesmas Bangetayu Semarang. Buletin Penelitian Kesehatan, 47(1), 23-28. https://doi.org/10.22435/bpk.v47i1.779

Nababan, B. B., Saraswati, L. D., \& Muniroh, M. (2018). Faktor-Faktor yang Berhubungan Dengan Kadar Gula Darah pada Penderita Diabetes Melitus Tipe 2 di RSUD K.R.M.T Wongsonegoro Semarang. Jurnal Kesehatan Masyarakat (eJournal), $6(1)$, 200-206. https://ejournal3.undip.ac.id/index.php/jkm/article/view/19866

Pereira, M. G., Pedras, S., Ferreira, G., \& Machado, J. C. (2019). Family and Couple Variables Regarding Adherence in Type 2 Diabetes Patients in the Initial Stages of the Disease. Journal of Marital and Family Therapy, 45(1), 134-148. https://doi.org/10.1111/jmft.12281

Pranata, L., Indraryati, S., \& Daeli, N. E. (2020). Perangkat Edukasi Pasien dan Keluarga dengan Media Booklet (Study Kasus Self-Care Diabetes Melitus). Jurnal Keperawatan Silampari, 4(1), 102-111. https://doi.org/10.31539/jks.v4i1.1599

Rhinehart, A. S., Condon, J. E., Beck, J., Reed, A. A., Mensing, C., Lavin-Tompkins, J. M., MacLeod, J., Cypress, M., Francis, T., Fischl, A. H., Bollinger, S. T., Pope, D. D., Butcher, M. K., Faulkner, P., Kolb, L. E., Maryniuk, M., Greenwood, D. A., Orzeck, E. A., Pulizzi, J. L., \& Blanton, L. (2017). 2017 National Standards for Diabetes Self-Management Education and Support. Diabetes Spectrum, 30(4), 301-314. https://doi.org/10.2337/ds17-0067

Sari, C. W. M., \& Yamin, A., \& Sari, P. S. (2018). Edukasi Berbasis Masyarakat untuk Deteksi Dini Diabetes Melitus Tipe 2. Media Karya Kesehatan, 1(1), 29-38. https://doi.org/10.24198/mkk.v1i1.17127

Sartika, A., Betrianita, B., Andri, J., Padila, P., \& Nugrah, A. (2020). Senam Lansia Menurunkan Tekanan Darah pada Lansia. Journal of Telenursing (JOTING), 2(1), 11-20. https://doi.org/10.31539/joting.v2i1.1126

Setyawati, A., Ngo, T., Padila, P., \& Andri, J. (2020). Obesity and Heredity for Diabetes Mellitus among Elderly. JOSING: Journal of Nursing and Health, 1(1), 26-31. https://doi.org/10.31539/josing.v1i1.1149

Yosmar, R., Almasdy, D., \& Rahma, F. (2018). Survei Risiko Penyakit Diabetes Melitus Terhadap Kesehatan Masyarakat Kota Padang. Jurnal Sains Farmasi Dan Klinis, 5(2), 134-141. http://dx.doi.org/10.25077/jsfk.5.2.134-141.2018

Zamaa, M. S., \& Sainudin, S. (2019). Hubungan Kepatuhan Pengobatan dengan Kadar Gula Darah Sewaktu pada Pasien Diabetes Melitus Tipe II. Jambura Nursing Journal, 1(1), 11-18. https://doi.org/10.37311/jnj.v1i1.2057 